\title{
Is Restorative Justice an Effective Approach in Responding to Children and Young People Who Sexually Harm?
}

\author{
Lisa Mary Armstrong (D)
}

check for

updates

Citation: Armstrong, Lisa Mary. 2021. Is Restorative Justice an Effective Approach in Responding to Children and Young People Who Sexually Harm?. Laws 10: 86. https://doi.org/10.3390/laws10040086

Academic Editor: Paul Gavin

Received: 6 October 2021

Accepted: 6 November 2021

Published: 12 November 2021

Publisher's Note: MDPI stays neutral with regard to jurisdictional claims in published maps and institutional affiliations.

Copyright: (c) 2021 by the author. Licensee MDPI, Basel, Switzerland. This article is an open access article distributed under the terms and conditions of the Creative Commons Attribution (CC BY) license (https:/ / creativecommons.org/licenses/by/ $4.0 /)$.
School of Law, University of Strathclyde, Glasgow G4 OLT, UK; lisa.armstrong.2018@uni.strath.ac.uk

\begin{abstract}
In the UK, Australia, and further afield, restorative programmes have been developed as a response to the failure of the criminal justice system to give victims of sexual violence a voice in the legal process. The restorative justice literature has tended to focus on sexual offences perpetrated by adults and the importance of being victim centred. When it is a child or young person (CYP) who sexually harms, it poses a unique set of challenges for law and society and the restorative practitioner. This article explores the reasons why a different approach may be warranted given the perceived failure of conventional criminal justice in addressing the growing problem of child and adolescent harmful sexual behaviour (HSB) in Scotland. It discusses the difficulties with balancing the rights of the victim with the CYP who perpetrates the HSB and considers the challenges encountered by practitioners in the implementation and application of restorative programmes in HSB cases involving CYP. Although the evidence supports a growing need for a different approach, and restorative justice may offer just that, problems with net widening, the referral process, and resistance from other professionals and victim advocacy groups present real barriers. Consequently, restorative practitioners are likely to find practising in this area more challenging due to a lack of support and cooperation.
\end{abstract}

Keywords: restorative justice; criminal justice; harmful sexual behaviour; sexual offences; children and young people

\section{Introduction}

Sexual offending against children is a highly emotive issue and one in which the law responds most punitively. When a child or young person (CYP) engages in harmful sexual behaviour (HSB), however, it presents a unique set of challenges for law and society. There is the difficult task of ensuring that the child's age, level of maturity, and 'best interests of the child' are taken into consideration while balancing this with the rights of the victim and the public interest. Some of these issues were considered in the high-profile case of HM Advocate v Aaron Campbell ${ }^{1}$, in which sixteen-year-old Campbell was convicted of the rape and murder of six-year-old Alesha MacPhail. During the appeal, the judge acknowledged that due to Campbell's status as a child, 'rehabilitation' and his 'future reintegration into society' ${ }^{2}$ were factors that should be taken into consideration when assessing the sentence length. The court concluded that the trial judge had failed to make allowance for the 'mitigatory effect of youth'3 and the sentence was subsequently reduced from 27 to 24 years.

In Scotland, those under the age of 18 are deemed 'children' for the purposes of court proceedings as set out in The Victims and Witnesses (Scotland) Act 2004 ${ }^{4}$. In addition, the United Convention on the Rights of the Child (UNCRC) (UN General Assembly 1989)

\footnotetext{
2019 SLT 1127.

Ibid, para. 9.

Ibid, para. 28.

Victims and Witnesses (Scotland) Act 2004. Available online: https:/ /www.legislation.gov.uk/asp/2014/1/contents (accessed on 12 July 2021).
} 
(which Scotland has since incorporated into domestic law) gives legal rights and protection to all children under 18 . There are reporting restrictions that apply under Section 47 Criminal Procedure (Scotland) Act $1995^{5}$ preventing the publication of the name or photographs of a child witness or accused by the media unless it is in the public interest. In the case of Aaron Campbell, however, the trial judge waived anonymity and allowed those details to be published, reasoning that due to the serious nature of the crime, it was in the public interest to do so (Tickell 2020).

This article considers the arguments for and against employing a restorative approach in cases of HSB perpetrated by a CYP using Scotland as a case study. It begins by providing an overview of how youth justice policy has developed historically in Scotland before exploring the reasons why a different approach may be warranted. This is given the perceived failure of conventional criminal justice in meeting the needs of victims of sexual offences and CYP who sexually harm, which is also a significant issue in many other countries (Anderson and Parkinson 2018; McGibbin and Humphreys 2021). The article then discusses the difficulties encountered by practitioners in the implementation and application of restorative programmes for CYP who engage in HSB.

\section{Background and Context}

The Kilbrandon Report (1964) has been cited as one of the most progressive policy statements of its time by practitioners, policymakers, and politicians (Scottish Government 1995; Lightowler et al. 2014). Developing a welfare-orientated system which considered the 'needs not deeds' of CYP under 16 years (and in some cases 18 years) resulted in a fundamental shift in how Scotland as a nation responded to children in conflict with the law. The Children's Hearing System (CHS) was given effect by the Social Work (Scotland) Act $1968^{6}$ and replaced the Scottish juvenile justice system. The ethos of the Kilbrandon philosophy recognised that children in trouble with the law required care and protection in similar ways to children who were victims of neglect and abuse. A key aim underpinning the system was to avoid the unnecessary criminalisation of children and the 'best interests of the child' were to be paramount in the decision-making process (McAra 2006). This approach set Scotland apart from England and Wales, where managerialism and risk dominated practice. McAra (2006, p. 2) explains however, that in the mid-1990s 'there was a degree of policy convergence with England and Wales' in which Scotland adopted elements of New Labour's tough on juvenile crime agenda. This was most notably through anti-social behaviour legislation (for example the infamous ASBO and Parenting Orders) which moved the focus from welfare and needs to behaviour' (McAra 2006). The AntiSocial Behaviour (Scotland) Act $2004^{7}$ allowed local authorities to make an application to a sheriff court in cases in which they had reason to believe that someone under 16 years had engaged in anti-social behaviour (Cleland and Tisdale 2004). This was criticised, as it ran counter to the Kilbrandon principles which stressed the primacy of the CHS as a forum for decision making about children (Cleland and Tisdale 2004).

In Scotland, the youth justice policy framework has been greatly influenced by the Kilbrandon philosophy. The Whole Systems Approach (WSA), for example, was introduced as a method of working with CYP 8-18 years who were involved in offending behaviours (Dyer and Carter 2017; Scottish Government 2021a). The WSA encourages an early intervention approach to steer CYP away from the criminal justice system (CJS) and brings agencies together to work collaboratively to achieve better outcomes for CYP (Scottish Government 2021b). When CYP are referred to the CHS on offence grounds, their needs and risks are assessed using the Getting it Right for Every Child framework (GIRFEC) which underpins the WSA (Scottish Government 2021a). This policy framework has been strengthened with the recent incorporation of the UNCRC, as Scotland moves

\footnotetext{
Criminal Procedure Scotland Act 1995. Available online: https://www.legislation.gov.uk/ukpga/1995/46/contents (accessed on 12 July 2021).

Social Work (Scotland) Act 1968. Available online: https:/ /www.legislation.gov.uk/ukpga/1968/49/contents (accessed on 12 July 2021).

Anti-Social Behaviour ect. (Scotland) Act 2004. Available online: https://www.legislation.gov.uk/asp/2004/8/contents (accessed on 1 August 2021).
} 
increasingly towards a rights-respecting nation, recognising that elevating the rights of children, including those in conflict with the law, is of fundamental importance (see, for example, Lightowler 2020).

\section{Children and Young People and Harmful Sexual Behaviour}

Harmful Sexual Behaviour (HSB) is a term used to describe a whole range of problematic sexual behaviours that CYP may engage in. Hackett et al. (2016) offer the following definition which has been adopted by the National Society for the Prevention of Cruelty to Children (NSPCC): 'Sexual behaviours expressed by children and young people under the age of 18 years old that are developmentally inappropriate, may be harmful towards self or others, or be abusive towards another child, young person or adult'.

HSB among CYP is a contentious issue and balancing the rights of victims and those who perpetrate the harm is a difficult task. A recent report published by the Scottish government (2020) explored the strengths and gaps in policy and guidance in relation to HSB and found that responding to and preventing HSB was somewhat of a challenge for practitioners and policymakers. Practitioners and frontline workers often struggle to manage these behaviours because of a lack of awareness and training around the causes of HSB (McGibbin and Humphreys 2021). This usually results in CYP who need support with their behaviour being criminalised and labelled as 'adolescent' or 'juvenile' sex offenders (Belton and Hollis 2016).

Changing how we perceive these behaviours is important, as the literature provides evidence that children's brain development continues into early adulthood (McEwan 2018; Lightowler 2020). In addition, the reasons CYP display or engage in HSB differ significantly from adults who perpetrate sexual offences. As CYP mature, they are therefore more likely to grow out of offending behaviours' (Scottish Government 2021a; McEwan 2018). HSB can also occur in a variety of different contexts such as peer-on-peer abuse, CYP with learning disabilities, internet pornography, and intrafamilial abuse, some of which are discussed below (Scottish Government 2020).

Scotland, similar to many other countries, has witnessed a significant increase in cyber-related sexual crimes amongst CYP (Moodie 2021; Scottish Government 2020; Quayle 2020). Research conducted in the UK suggests that one-third of all HSB against CYP is committed by CYP (Hackett et al. 2016). Technological advances have led to changes in the way sexual offences are perpetrated. The evidence reveals that CYPs are more likely to have been exposed to explicit content such as sexualised and pornographic images through the media and the internet (Scottish Government 2020). It is widely acknowledged that internet pornography has a harmful impact on boys and young men and contributes to sexual violence against women (Bensimon 2007; Flood and Hamilton 2003). Kirby (2021, p. 6) explains that the effect is caused by teaching 'sexist and sexually objectifying understandings of gender and sexuality and causes problems with sexual development, function, mental health and intimate relationships'. This gives boys and young men an unrealistic and unhealthy perception of how sex occurs in the context of and out with relationships.

Technology-assisted HSB (TA-HSB) is sexualised behaviour carried out with the use of internet technology (McEwan 2018). The production and sharing of intimate images, for example, are a specific problem among young people who increasingly use mobile technologies and social media platforms as their main means of communication (Kendall 2012; Ringrose et al. 2012). The Abusive Behaviour and Sexual Harm (Scotland) Act $2016^{8}$ makes it an offence to share or threaten to share intimate images in Scotland. This captures a wide range of harmful behaviours such as sexting, upskirting, and image-based sexual abuse often unhelpfully referred to as 'revenge porn' (for example see Ringrose et al. 2012). Many of these offences are gender specific. Sexting, for example, which is defined as 'the

8 Abusive Behaviour and Sexual Harm (Scotland) Act. 2016. Available online: https://www.legislation.gov.uk/asp/2016/22/contents/enacted (accessed on 14 August 2021). 
creating and forwarding of sexually suggestive nude or nearly nude images' is most often experienced by girls (Lenhart 2009).

Johnson and Doonan (2006, p. 113) explain that CYPs sexuality and emotional and cognitive awareness and relationship world' differs in important ways from adults and stress that failure to take this into consideration is dangerous. They warn that 'using vague and imprecise terminology can lead to the misclassification of CYP and labelling them inappropriately' (Johnson and Doonan 2006, p. 113). CYPs' sexual behaviour exists on a wide spectrum. Vulnerable groups such as children with learning and cognitive disabilities, for example, are found to make up a significant proportion of referrals to HSB services. Less than $10 \%$ of sexual offences are, however, committed by girls, and the prevalence of learning disabilities among those who engage in HSB is particularly high among young females (Hackett et al. 2016; Almond and Giles 2008). A research project that mapped service provision for YP displaying HSB found that between 2011 and 2012 Scotland and England's local authorities reported more cases involving young males from ethnic minorities (Smith et al. 2013; Hackett et al. 2016). The evidence indicates that those children who do engage in HSB are more likely to have a history of victimisation and of being sexually abused (Smith et al. 2013).

Nevertheless, it has been suggested that the most effective way of managing HSB in CYP is by using a multi-agency and tertiary approach (Scottish Government 2020). HSB should be framed as a public health problem and requires involvement from education and health of whom both have a key role to play in primary prevention. There are, however, other approaches to managing HSB in CYP-namely, restorative justice (RJ). RJ has been used widely in the field of youth justice, but there has been a tendency to steer away from hard cases (Hudson 2002). In Scotland, although RJ does exist (albeit provision is patchy), it is used for low-level offending in children and youths. These services have had little impact on the CJS (Tutt 1997; Maglione et al. 2020) which has been attributed to a lack of policy direction (Maglione 2020; Maglione et al. 2020). This can be contrasted with other parts of the UK, such as England and Northern Ireland, where RJ is much more embedded in the CJS. Recently, the Scottish Government (2019) recognised the efficacy of integrating $\mathrm{RJ}$ into criminal justice practice and is aiming to expand RJ services widely across Scotland by 2023. There are, however, significant challenges around mainstreaming RJ into practice. The next part of this article discusses the practicalities involved when implementing such initiatives for CYP who sexually harm.

3.1. Practicalities of Implementation and Application of Restorative Programmes for Children and Young People Who Sexually Harm

Sexual violence as experienced by women and children is a pervasive issue. The barriers encountered by victim-survivors in the reporting of sexual crimes and stories of their journey through the CJS serve to actively discourage disclosure (Baird 2019). As a result, victim-survivors often voice that they feel let down by the justice system which is a blunt tool in addressing the complexities of sexual violence and HSB. There may be situations where the victim develops a desire to meet the person who has harmed them, and indeed there are countries such as Australia, New Zealand, and Denmark where this is possible through what is known as a restorative justice encounter or meeting (McGlynn et al. 2012; Mercer and Madesen 2015; Zinsstag and Keenan 2017). Due to the sensitive and emotive nature of the crime, restorative justice practitioners do not advertise their services preferring instead to practice 'under the radar' (Zinsstag and Keenan 2017). 
Cossins (2008) has highlighted the growth in research of RJ in cases involving domestic abuse and sexual offences (for example, Hudson 2002; Morris and Gelsthorpe 2000; McAlinden 2005; Zinsstag and Keenan 2017). RJ has also been utilised in cases of sexual violence worldwide, including Australia (Daly and Wade 2017, pp. 143-79), New Zealand (Jülich and Bowen 2015), and the UK (Anderson and Parkinson 2018). The Daphne Project was a two-year project led by researchers interested in how RJ could be used in response to cases involving sexual violence (Mercer and Madesen 2015). In particular, it evaluated the AIM project in England which works specifically with CYPs who engage in HSB. Mercer (2020) who runs the programme notes that, aside from the referral order and conferencing service in Northern Ireland (see, for example, Campbell et al. 2005, Evaluation of the NI Youth Conference Service), RJ has not worked in the area of sexual violence. He explains that practitioners will purposively avoid it due to the difficulties encountered in practice. Mercer (2020) argues that despite this it can have a considerable impact on those involved by giving the victim and those who have harmed the opportunity to ask questions that the CJS is not designed to answer. In addition, he underlines the importance of ensuring that victims are adequately supported during and after the process (Mercer and Madesen 2015).

$\mathrm{RJ}$ is often deemed unsuitable because of the perceived power imbalance that can occur between victim and perpetrator in cases of sexual violence. Many victim advocacy and women's rights groups have objected to the use of RJ due to possible coercion and the increased risk it presents to victims. When it is a CYP who has engaged in HSB, balancing the rights of both the victim and the child who has harmed is challenging due to coercion and the risks presented on both sides. The media hyperbole that surrounds the reporting of youth and sexual offending often leads to moral panic (Cohen [1972] 2002; Klein and McKissick 2019). In the past, this has driven policy and legislative responses in the management of those who commit sexual crimes. What was witnessed in the advent of sex offender notification schemes was the resultant net widening of similar or the same punitive measure against those termed 'juvenile sex offenders' (Sterling 2015). The inclusion of CYPs on the sex offender registry can, therefore, have a serious impact on their life chances. The AIM project has since published practice guidance on the use of restorative practices in cases of CYPs who engage in HSB (Mercer 2020). A discussion of the practicalities of application and specific challenges encountered by those delivering RJ programmes in this area will now follow.

\subsection{The Barriers to Implementation}

The AIM project is an established UK and international organisation that works with CYP with HSB. Initially, the majority of AIM's work focussed on intrafamilial/sibling sexual abuse but they have since expanded their services to encompass cases that involve technology-assisted HSB. In their article, Henniker and Mercer (1999) discuss some of the specific challenges AIM practitioners encountered when using RJ in cases involving intrafamilial/sibling abuse. For example, they explained that some parents and family members could experience mixed loyalties and feel divided if both victim and the child who has harmed are their children, siblings, grandchildren, etc. However, from a victim's perspective, it was reported that there was a distinct lack of services available to support victims through the restorative process and a lack of external evaluation (Henniker and Mercer 1999).

In a study conducted by Daly and Wade (2017, p. 146), in which they analysed seventeen cases of youth sibling sexual violence in Australia, they found that 'the dynamics of sibling sexual assault and justice system responses differed from other types of youth sexual offending in key ways'. For example, the offending was more serious and yet a higher proportion of cases were referred to a Family Group Conference (FGC) than court. Most victims were too young to participate in a conference, and they found that the process centred mainly on ways to prevent youths from further offending. It was noted that parents, the majority of whom were mothers, 'had an emotionally complex dual role of representing their victim-child and the child who had perpetrated the harm' (Daly and 
Wade 2017, pp. 37-38). Interestingly, Anderson and Parkinson (2018) have promoted the use of an HSB-FGC framework, arguing that it could potentially accommodate the welfare and justice needs of all young people involved. Cossins (2008) concludes, however, that $\mathrm{RJ}$ is not a panacea for sexual assault cases due to the fact that it can only be applied to a small minority of cases. This is echoed to some extent by Anderson and Parkinson (2018), who admit that FGCs will not always be the appropriate venue for every case involving sexual violence.

Hudson (2002), on the other hand, argues that CYPs in conflict with the law cannot grow out of crime if punished and stigmatised, as this restricts their life chances. She explains that those critics that argue against applying RJ to hard cases such as sexual violence and domestic abuse fail to consider whether there are standards and safeguards that could make it work for victims and advocates for using an RJ approach in sexual offences 'fail to address the questions of procedural safeguards and outcomes' for those who have harmed (Hudson 2002, p. 4). Risk assessments are routinely carried out to determine the psychological and emotional readiness of the victim to meet the perpetrator in RJ cases involving serious offences (Bremer 2006). The following core eligibility criteria are used in South Australia, for example, to assess whether the victim is 'participant ready': the victim has the capacity to consent, provides free and informed consent, and fully understands their rights. When the victim is a child, protecting them and ensuring their consent is voluntary and not coerced is of fundamental importance. Children who offend, however, are equally as vulnerable and at risk of being coerced into participating in a restorative process. It is, therefore, vital that practitioners and other adults who are participating in the process are guided by 'the best interests of the child' principle and international, national, and domestic children's rights frameworks.

Whereas Lynch (2010, p. 173) advances that while the 'primary aims of the adult criminal justice system is to hold offenders accountable for their actions and to protect the interests and safety of the public, the appropriate weight to be placed on the youth justice system is less clear'. She elaborates further that 'intuitively it seems right that wrongdoers should be penalised and victims should be compensated for the wrong done to them but a victim centred approach is not in line with the special characteristics of children' (Lynch 2010, p. 173). The youth justice system should be 'offender focussed' by its very nature and Lynch notes that moving towards an increasingly victim-centred restorative approach 'would not be in compliance with the requirement to have a young person-centred youth justice system' (Lynch 2010, p. 173). Advocates have claimed that RJ is sometimes used too loosely as an umbrella term to describe practices that are far from restorative. Police restorative warnings in Scotland, for example, utilised diversionary processes to prevent children from becoming entangled in the CJS, however, has instead led to the net widening of youth (Miers 2001; O'Mahony and Campbell 2006).

New restorative initiatives and programmes encounter significant barriers when trying to generate adequate referrals and in establishing referral pathways (Crawford and Newburn 2011). Crawford and Newburn (2011) explain that the success of schemes very much depends on obtaining the buy-in from criminal justice agencies such as the police, prosecution service, courts or probation, and prison service and appropriate referrals. A particular issue that the Sacro Youth Service in Scotland encountered when the General Data Protection Regulation was first introduced, was a significant drop in the RJ referrals from police and criminal justice agencies (Children and Young People's Centre for Justice 2020). The changes in data protection regulations led to the review of protocols which required people to opt in to having their details shared with other agencies. In addition, professionals may not 'share a restorative justice philosophy, have differing organisational priorities or approaches to case management or may not appreciate the criteria under which schemes work' (Crawford and Newburn 2011, p. 40). There may also be little or no consequences of not referring cases, and the referral problem brings forth issues when evaluating the effectiveness of restorative interventions, as it 'introduces elements of bias and self-selection' (Crawford and Newburn 2011, p. 40). 


\section{Conclusions}

To conclude, due to the rapid advances in technology which have led to a significant growth in HSB perpetrated by CYP (Scottish Government 2020), we desperately need to see more innovative ways of responding to HSB. This is not a problem that is unique to Scotland either but a much wider issue-practitioners in other countries have reported real challenges when trying to manage this type of behaviour (McGibbin and Humphreys 2021). The NSPCC guidelines on ways to improve responses to HSB have framed this growing problem as a child protection issue which requires a therapeutic response rather than criminal sanctions. Restorative approaches run alongside intervention programmes such as the AIM project are one among many possible responses. This would involve RJ practitioners, child psychology, social work, and youth justice working collaboratively in order to improve the life chances and outcomes for victims and CYP who engage in HSB and their families.

The criminal justice system may be the appropriate arena for managing adults who commit sexual offences, but there is considerable evidence to suggest that it is not the right response for CYP who engage in HSB (Scottish Government 2020; Johnson and Doonan 2006; Sterling 2015). However, RJ, as an approach to CYP who engage in HSB, is still very much in its infancy in the UK, and although programmes do exist in other jurisdictions, even they are relatively rare (Mercer and Madesen 2015). In addition, Scotland appears to be lagging behind other countries where $\mathrm{RJ}$ is more firmly embedded in the youth and criminal justice system. This provides additional challenges in terms of implementing new restorative initiatives (Crawford and Newburn 2011; Zinsstag and Keenan 2017, pp. 143-79; Maglione 2020). As with diversion from prosecution schemes, there is also the danger that RJ may be used inappropriately for offences which may not have previously attracted attention or no sanction leading to net widening (Shapland et al. 2011).

Although the literature provides us with evidence that RJ can empower victims of sexual violence and offer them the opportunity to seek answers to the questions the CJS cannot provide, practitioners report real barriers to employing a restorative approach in these cases. This may include net widening and difficulties with implementation, such as establishing referral pathways, and in the referral process itself. Furthermore, resistance from other professionals and victim advocacy groups is an additional concern since, without their support and cooperation, it is unlikely that we will see an increase in the number of programmes or practitioners willing to work in this area.

Funding: This research received no external funding.

Institutional Review Board Statement: Not applicable.

Informed Consent Statement: Not applicable.

Conflicts of Interest: The author declares no conflict of interest.

\section{References}

Almond, Louise, and Susan Giles. 2008. Young people with harmful sexual behaviour: Do those with Learning Disabilities form a distinct subgroup? Journal of Sexual Aggression 14: 227-39. [CrossRef]

Anderson, Monique, and Kate Parkinson. 2018. Balancing Justice and Welfare Needs in Family Group Conferences for Children with Harmful Sexual Behaviour: The HSB-FGC Framework. Journal of Child Sexual Abuse 27: 490-509. [CrossRef] [PubMed]

Baird, Vera. 2019. Thousands of Rape Victims Are Being Denied Justice. The CPS and Police Must Do Better. The Guardian. Available online: https:/ / www.theguardian.com/commentisfree/2019/sep/19/help-rape-victims-cps-police-change-attitudes (accessed on 2 November 2021).

Belton, Emma, and Vicki Hollis. 2016. A Review of the Research on Children Who Display Harmful Sexual Behaviour. London: NSPCC. Available online: https: / learning.nspcc.org.uk/research-resources/2016/review-children-young-people-harmful-sexual-behaviouronline (accessed on 12 May 2021).

Bensimon, Philipe. 2007. The role of pornography in sexual offending. Sexual Addiction and Compulsivity 14: 95-117. [CrossRef]

Bremer, Janis F. 2006. Juveniles Who Engage in Sexually Harmful Behaviour: A Restorative Justice System. William Mitchell Law Review 32: 1-9. Available online: https:/ /open.mitchellhamline.edu/wmlr/vol32/iss3/15/ (accessed on 15 May 2021). 
Campbell, Catriona, Roison Devlin, David O’Mahony, Jonathan Doak, John Jackson, Tanya Corrigan, and Keiran McEvoy. 2005. Evaluation of the Northern Ireland Youth Conference Service. Belfast: Northern Ireland Office.

Children and Young People's Centre for Justice. 2020. Restorative Justice: Practioner Case Studies. University of Strathclyde. Available online: https: / / www.cycj.org.uk (accessed on 1 November 2021).

Cleland, Alison, and Kay Tisdale. 2004. The Challenge of Antisocial Behaviour Paper Given at Antisocial Behaviour Conference, Glasgow. Available online: https://www.gla.ac.uk/schools/socialpolitical/research/urbanstudies/events/urbanstudiesseminarseries/ eventsnewsarchive/2006-09/anti-socialbehaviourconference-presentations / (accessed on 16 August 2021).

Cohen, Stanley. 2002. Folk Devils and Moral Panics: The Creation of the Mods and Rockers, 3rd ed. London: Routledge. First published 1972.

Cossins, Annie. 2008. Restorative Justice and Child Sex Offences. British Journal of Criminology 48: 359-78. [CrossRef]

Crawford, Adam, and Tim Newburn. 2011. Youth Offending and Restorative Justice: Implementing Reform in Youth Justice. Abingdon: Routledge.

Daly, Kathleen and Danielle Wade. 2017. Sibling Sexual Violence and Victims Justice Interests: A Comparison of Conferencing and Judicial Sentencing. In Restorative Responses to Sexual Violence: Legal, Social and Therapeutic Dimensions. Edited by Estelle Zinsstag and Marie Keenan. Abingdon: Routledge Taylor and Francis Group, pp. 143-79.

Dyer, Fiona, and Kevin Carter. 2017. Supporting Young People Involved in Offending up to 21 Years Old: Extending the Whole System Approach. University of Strathclyde. Available online: https://strathprints.strath.ac.uk/68168/ (accessed on 23 August 2021).

Flood, Michael, and Clive Hamilton. 2003. Regulating Youth Access to Pornography. (Discussion Paper No 53). Canberra: The Australia Institute. Available online: https:/ /www.academia.edu/444491/Regulating_Youth_Access_to_Pornography_2003_(accessed on 23 August 2021).

Hackett, Simon, Dez Holmes, and Pat Branigan. 2016. Harmful Sexual Behaviour Framework: An Evidence Informed Operational Framework for Children and Young People Displaying Harmful Sexual Behaviours. London: NSPCC.

Henniker, Julie, and Vince Mercer. 1999. Restorative Justice: Can it work with young people who sexually abuse? In Working with Young People Who Sexually Abuse. Edited by Martin Calder. Lyme Regis: Russell House Publishing.

Hudson, Barbara. 2002. Restorative Justice and Gendered Violence. British Journal of Criminology 42: 616-34. [CrossRef]

Johnson, Toni Cavanagh, and Ronda Doonan. 2006. Children twelve and younger with sexual behaviour problems. What we know in 2005 that we didn't know in 1985. In Current Perspective: Working with Sexually Aggressive Youth and Youth with Sexual Behaviour Problems. Edited by Robert Longo and David Prescott. Holyoke: NEARI Press.

Jülich, Shirley, and Helen Bowen. 2015. Restorative Justice in Aotearoa, New Zealand: Improving Our Response to Sexual Violence. Social Work Review 14: 93-104.

Kendall, Holly. 2012. Teenage Sexting: The Symptom Not the Problem. Available online: http://rightnow.org.au/topics/children-andyouth/teenage-sexting-the-symptom-not-the-problem/ (accessed on 14 June 2021).

The Kilbrandon Report. 1964. Report on the Committee on Children and Young Persons, Scotland; (Cmnd 2306); Edinburgh: Scottish Home and Health Department/Scottish Education Department.

Kirby, Mike. 2021. Pornography and its impact on the sexual health of men. Trends in Urology and Men's Health 12: 6-10. [CrossRef]

Klein, Jennifer L., and Alexandra B. McKissick. 2019. Moral Panics and Community Members Perceptions Regarding Reductions in Sex Offender Recidivism. Justice Policy Journal 16: 1-24.

Lenhart, Amanda. 2009. Teens and Sexting: How and Why Minor Teens Are Sending Sexually Suggestive Nude or Nearly Nude Images via Text Messaging. Pew Research Centre Report. Available online: https:/ / www.semanticscholar.org/paper/Teens-andSexting\%3A-How-and-why-minor-teens-are-nude-Lenhart/261947313cb03400a1b1c04a9816fa1ee0a4c3bf (accessed on 17 August 2021).

Lightowler, Claire. 2020. Rights Respecting? Scotland's Approach to Children in Conflict with the Law University of Strathclyde. Available online: https:/ / pureportal.strath.ac.uk/en/publications/rights-respecting-scotlands-approach-to-children-in-conflictwith (accessed on 17 July 2021).

Lightowler, Claire, David Orr, and Nina Vaswani. 2014. Youth Justice in Scotland: Fixed in the Past or Fit for the Future? [Report]. University of Strathclyde. Available online: https://strathprints.strath.ac.uk/50496/ (accessed on 1 November 2021).

Lynch, Nessa. 2010. Restorative Justice through a Child's Lens. International Journal of Children's Rights 18: 161-83. [CrossRef]

Maglione, Giuseppe. 2020. Restorative Justice, Crime Victims and Penal Welfarism: Mapping and Contextualising Restorative Justice Policy in Scotland. Social and Legal Studies 30: 745-67. [CrossRef]

Maglione, Giuseppe, Jamie Buchan, and Laura Robertson. 2020. The Local Provision of Restorative Justice in Scotland: An Exploratory Empirical Study. European Journal on Criminal Policy and Research 1-24. [CrossRef]

McAlinden, Anne-Marie. 2005. The Use of 'Shame' with Sexual Offenders. British Journal of Criminology 45: 373-94. [CrossRef]

McAra, Lesley. 2006. Welfare in Crisis? Youth Justice in Scotland. In Comparative Youth Justice: Critical Debates. Edited by John Muncie and Barry Goldson. London: Sage Publications Ltd., pp. 127-45.

McEwan, Donna. 2018. Caught in the Net! Technology Assisted Harmful Behaviours Info Sheet CYCJ. University of Strathclyde. Available online: http:/ / www.cycj.org.uk/resource/caught-in-the-net-technology-assisted-harmful-sexual-behaviours / (accessed on 1 November 2021).

McGibbin, Gemma, and Cathy Humphreys. 2021. Frontline Workers' Response to Harmful Sexual Behavior: Building Blocks for Promising Practice. Trauma, Violence and Abuse 1-16. [CrossRef] [PubMed] 
McGlynn, Clare, Nicole Westmarland, and Nikki Godden. 2012. 'I just wanted him to hear me': Sexual Violence and the Possibilities of Restorative Justice. Journal of Law and Society 39: 213-40. [CrossRef]

Mercer, Vince. 2020. The AIM Restorative Practice and Harmful Sexual Behaviour Assessment Framework and Practice Guidance The AIM Project. Available online: https:/ / aimproject.org.uk/vince-mercer/ (accessed on 27 July 2021).

Mercer, Vince, and Karin Sten Madesen. 2015. Doing Restorative Justice in Cases of Sexual Violence: A Practice Guide. Edited by Marie Keenan and Estelle Zinsstag. Belgium: Leuven Institute of Criminology. Available online: https://www.law.kuleuven.be/linc/ english/research/researchdaphnesexualviolence.html (accessed on 13 May 2021).

Miers, David. 2001. An International Review of Restorative Justice. London: Home Office.

Moodie, Kristina. 2021. Harmful Sexual Behaviours by Children CYCJ. University of Strathclyde. Available online: http:/ /www.cycj. org.uk/news / cycj-examines-harmful-sexual-behaviours-by-children/ (accessed on 14 August 2021).

Morris, Allison, and Loraine Gelsthorpe. 2000. Something Old, Something Borrowed, Something Blue but Something New? A Comment on the Prospects for Restorative Justice under the Crime and Disorder Act 1998. Criminal Law Review 2: 18-30.

O'Mahony, David, and Catriona Campbell. 2006. Mainstreaming Restorative Justice for Young Offenders through Youth Conferencing: The Experience of Northern Ireland. In International Handbook of Juvenile Justice. Edited by Josine Junger-Tas and Scott H. Decker. New York: Springer, pp. 93-115.

Quayle, Ethel. 2020. Prevention, disruption and deterrence of online child sexual exploitation and abuse. Journal of the Academy of European Law 21: 429-47. Available online: https://link.springer.com/article/10.1007/s12027-020-00625-7 (accessed on 2 November 2021). [CrossRef]

Ringrose, Jessica, Rosalind Gill, Sonia Livingstone, and Laura Harvey. 2012. A Qualitative Study of Children, Young People and 'Sexting': A Report Prepared for the NSPCC. London: NSPCC. Available online: http:/ / eprints.lse.ac.uk/44216/ (accessed on 13 June 2021).

Scottish Government. 1995. The Kilbrandon Report; Edinburgh: HMSO. Available online: https://www.gov.scot/publications/ kilbrandon-report/pages/4/ (accessed on 3 May 2021).

Scottish Government. 2019. Restorative Justice Action Plan; Edinburgh: Scottish Government. Available online: https://www.gov.scot/ publications/restorative-justice-action-plan/documents/ (accessed on 15 May 2021).

Scottish Government. 2020. Harmful Sexual Behaviour by Children and Young People: Expert Group Report. Available online: https: / /www.gov.scot/publications/expert-group-preventing-sexual-offending-involving-children-young-people-preventionresponses-harmful-sexual-behaviour-children-young-people/ (accessed on 15 May 2021).

Scottish Government. 2021a. Youth Justice Strategy 2015 to 2020: Delivery of the Priorities-Progress Report; Edinburgh: Scottish Government. Available online: https://www.gov.scot/publications/youth-justice-strategy-2015-20-delivery-priorities/documents / (accessed on 17 May 2021).

Scottish Government. 2021b. Working with Children in Conflict with the Law 2021: Standards. Available online: https://www.gov. scot/publications/standards-those-working-children-conflict-law-2021/documents / (accessed on 24 May 2021).

Shapland, Joanna, Gwen Robinson, and Angela Sorsby. 2011. Restorative Justice in Practice: Evaluating What Works for Victims and Offenders. Abingdon: Routledge Taylor Francis Group.

Smith, Connie, Anne Lazenblatt, Caroline Bradbury-Jones, and Julie Taylor. 2013. Provision for Young People Who Have Displayed Harmful Sexual Behaviour (Full Report). The University of Edinburgh/NSPCC Child Protection Research Centre. Available online: https: / / www.research.ed.ac.uk/en/publications/provision-for-young-people-who-have-displayed-harmful-sexualbeha (accessed on 4 November 2021).

Sterling, Robin Walker. 2015. Juvenile Sex Offender Registration: An Impermissible Life Sentence? University of Chicago Laww Review 82: 295-315.

Tickell, Andrew. 2020. Why don't sexual offence complainers have a right to anonymity in Scotland? Edinburgh Law Review 24: 427-34. [CrossRef]

Tutt, Norman. 1997. Restorative justice in practice in Great Britain and Ireland. European Journal on Criminology, Policy and Research 5: 99-112. [CrossRef]

UN General Assembly. 1989. Convention on the Rights of the Child. United Nations, Treaty Series. vol. 157, pp. 3-178. Available online: https: / / www.ohchr.org/en/professionalinterest/pages/crc.aspx (accessed on 14 August 2021).

Zinsstag, Estelle, and Marie Keenan. 2017. Restorative Responses to Sexual Violence: Legal, Social and Therapeutic Dimensions. Abingdon: Routledge. 